\title{
An Oligocene toadfish (Teleostei, Percomorpha) from Moravia, Czech Republic: The earliest skeletal record for the order Batrachoidiformes
}

\author{
TOMÁŠ PŘIKRYL \& GIORGIO CARNEVALE
}

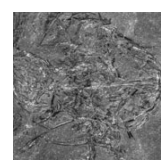

\begin{abstract}
The fossil record of toadfishes (Batrachoidiformes) is meager, with only scarce skeletal remains. The Menilitic Formation (Dynów Member) has provided the first and only Oligocene articulated skeleton of a toadfish, described herein as $\dagger$ Louckaichthys novosadi gen. et sp. nov. based on an incomplete partially articulated skeleton. The new taxon is characterized by a peculiar combination of features that clearly demonstrates its distinct generic status within the Batrachoidiformes, including: oblong subopercle with a single spine and no filaments; opercle with two spines and a single filament; preopercle with well-developed articular pedicel at the confluence of the vertical and horizontal arms; robust hyomandibula with well-developed articular, opercular and preopercular processes; and at least two pairs of epineurals hypertrophied and robust. Furthermore, the unique combination of features does not allow the inclusion of this new taxon within any of the known extant subfamilies. - Key words: Teleostei, Batrachoidiformes, Oligocene, Menilitic Formation, Paratethys.
\end{abstract}

PřIKRYl, T. \& CARnevale, G. 2017. An Oligocene toadfish (Teleostei, Percomorpha) from Moravia, Czech Republic: The earliest skeletal record for the order Batrachoidiformes. Bulletin of Geosciences 92(1), 123-131 (4 figures). Czech Geological Survey, Prague. ISSN 1214-1119. Manuscript received February 13, 2017; accepted in revised form March 20, 2017; published online March 31, 2017; issued March 31, 2017.

Tomáš Přikryl, Institute of Geology of the Czech Academy of Sciences, v.v.i., Rozvojová 269, 16500 Praha 6, Czech Republic \& Institute of Geology and Palaeontology, Charles University, Albertov 6, 12843 Praha 2, Czech Republic; prikryl@gli.cas.cz・Giorgio Carnevale, Dipartimento di Scienze della Terra, Università degli Studi di Torino, Via Valperga Caluso, 35, I-10125 Torino, Italia; giorgio.carnevale@unito.it

Toadfishes of the family Batrachoididae are the sole members of the order Batrachoidiformes, a group of primarily coastal benthic fishes distributed in tropical to temperate marine and brackish waters of the Atlantic, Indian and $\mathrm{Pa}$ cific oceans (Greenfield et al. 2008), with a few species being restricted to the freshwaters of South America (e.g., Collette 1995). This morphologically well-defined group was included for a long time within the Paracanthopterygii (e.g., Greenwood et al. 1966, Rosen \& Patterson 1969, Patterson \& Rosen 1989) as closely allied with the Lophiiformes in the Pediculati. Recent molecular studies, however, have revealed their basal position within percomorphs (e.g., Betancur-R. et al. 2013, Chen et al. 2014). The recent taxonomic analysis of the family Batrachoididae on a worldwide basis by Greenfield et al. (2008) recognized 23 extant genera in four monophyletic subfamilies, the Batrachoidinae, Halophryninae, Porichthyinae, and Thalassophryninae. Although the Batrachoididae comprises slightly less than 80 extant species, they are poorly represented in the fossil record (Carnevale \& Collette 2014). Articulated skeletal remains are currently known only from the Miocene of Algeria, Austria and Italy (Arambourg 1927, Carnevale 2004, Carnevale \& Collette 2014), while isolated bones have been reported from Miocene to Pleistocene deposits of the Middle Atlantic Coastal Plain of North America (Ray et al. 1968, Purdy et al. 2001, Carnevale \& Godfrey in press). Therefore, while the oldest skeletal remains of these fishes date back to the Serravallian (Carnevale \& Collette 2014), the otolith record of toadfishes extends back at least to the Ypresian of France (Nolf 1988), and numerous otolith-based taxa are known from the Priabonian of Italy (Girone \& Nolf 2009, Nolf 2013), and Rupelian of France (Nolf 2013). The Late Cretaceous Bacchiaichthys zucchiae from the paralic deposits of Trebiciano, Italy (Bannikov \& Sorbini 2000, Carnevale \& Johnson 2015) seems to exhibit several batrachoidiform features; however, any attribution to the toadfishes cannot be confirmed until a much more detailed analysis of the skeletal morphology of this fish will be available in order to conclusively demonstrate its phylogenetic affinities. Since the Miocene, batrachoidiforms become rather common (e.g., Landini et al. 2002a, 2002b; Carnevale et al. 2006, 2008, 


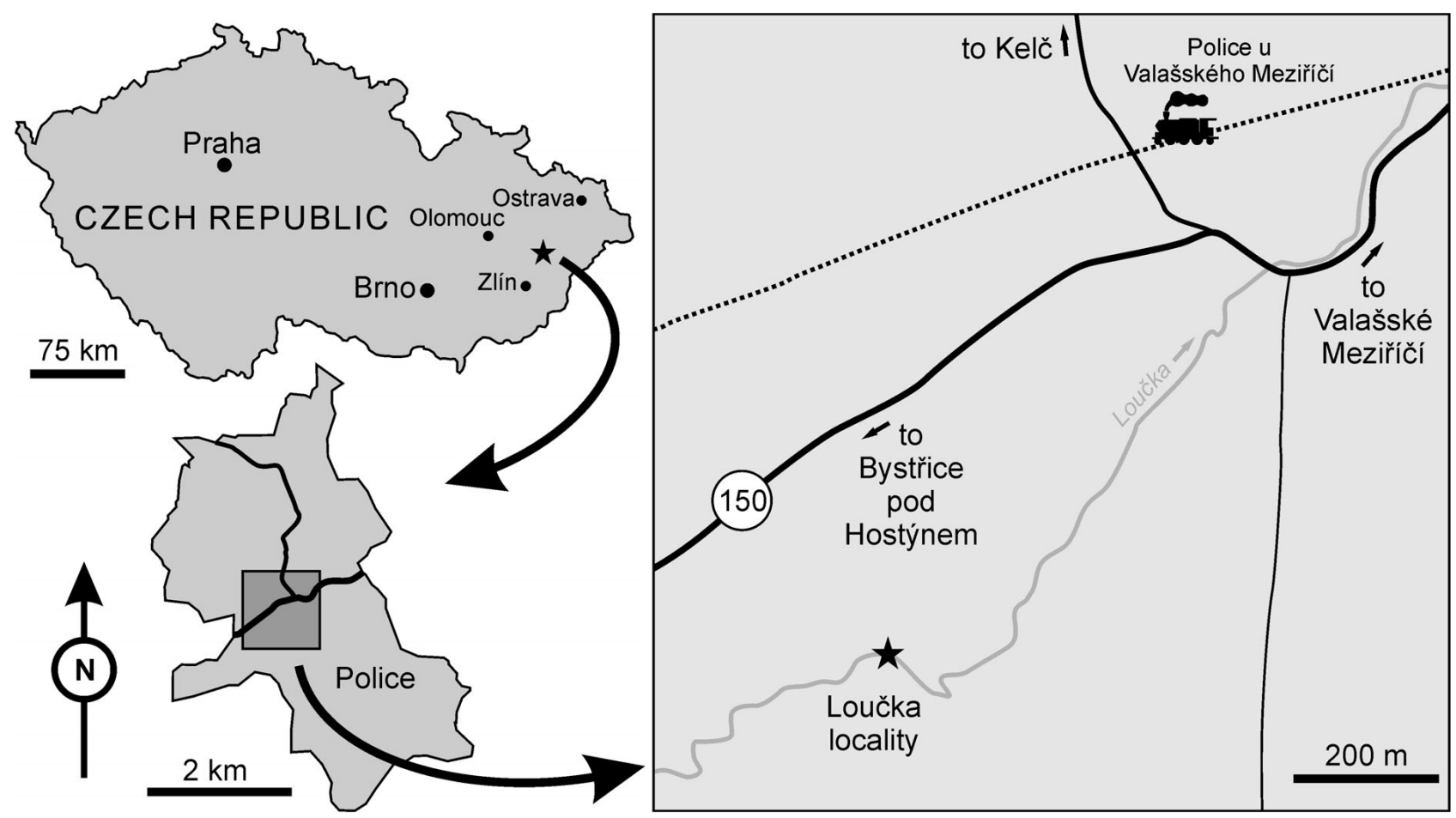

Figure 1. Sketch of the Czech Republic showing the location of the Loučka locality.

2011; Nolf 2013) and at least three of the four main batrachoidid lineages (Batrachoidinae, Halophryninae, Porichthyinae) were in existence (Carnevale \& Collette 2014). The goal of this paper is to describe a new genus and species of toadfish from the Rupelian Menilitic Formation of the Loučka locality (Moravia, Czech Republic), representing the first Oligocene articulated toadfish skeleton and most probably the oldest skeletal record of the order Batrachoidiformes (see below).

The sediments of the Rupelian Menilitic Formation in the Carpathian Flysch zone (32 Ma) have provided rich and diverse fish assemblages. For example, representatives of 15 teleost families and of five elasmobranch families have been recognized in the Dynów Marlstones at the Litenčice locality (e.g., Gregorová 1988, 2011; Přikryl 2009; Cappetta et al. 2016; Gregorová et al. 2016). The Loučka locality shows an almost complete exposition of the Menilitic Formation from the Subchert to the Dynów members; the Šitbořice Member is not represented in this locality (Stráník 1981; Bubík, personal communication). The locality, especially the uppermost portion of the exposed section (Dynów Member), has been explored for several years by one of us (T.P.), together with paleontologists of the National Museum, Prague and local collectors, result- ing in the accumulation of a rich assemblage currently under study (Přikryl et al. 2012, ongoing research); it includes sharks, clupeids, gonostomatids, argentinids, gadiforms, perciforms, ophidiiforms, and the new batrachoidiform genus and species documented herein.

\section{Material and methods}

The holotype and only known specimen in part (NMP Pv 10052a) and counterpart (NMP Pv 10052b) is deposited in the National Museum in Prague (NMP). The specimen is preserved on the surface of brown-grey marl with bones that appear grey or greenish (bones are yellowish when fragmented).

The Loučka locality (Silesian Unit) is located about 800 meters south-west from "Police" near the Valašské Meziřičí train station, along the left bank of the Loučka stream (Fig. 1). A large part of the Rupelian Menilitic Formation is exposed in this locality, including the Subchert, Chert, and Dynów members (Stráník 1981; Bubík, personal communication). A detail geological and stratigraphic description of the locality, together with a description and analysis of fossil assemblage, is currently in preparation.

Figure 2. †Louckaichthys novosadi gen. et sp. nov. from the Oligocene of the Loučka locality. Holotype. • A - NMP Pv 10052a. • B - interpretative drawing of the A. $\cdot$ C - NMP Pv 10052b, counterpart of NMP Pv 10052a. 

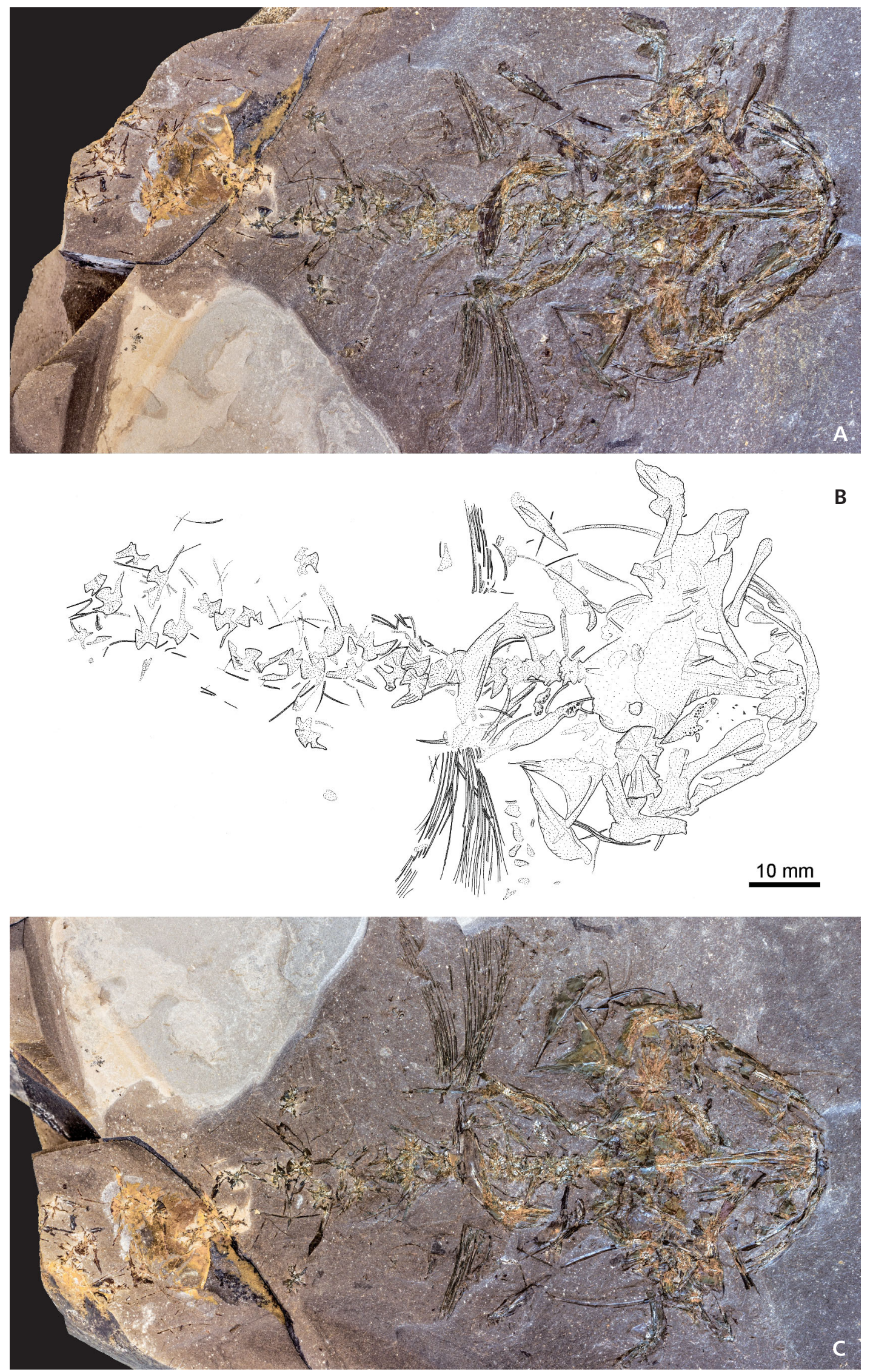
The fossil was studied using a Leica MZ6 stereomicroscope equipped with a camera lucida drawing arm. The measurements were taken with a dial caliper, to the nearest $0.1 \mathrm{~mm}$. All extinct taxa are marked with a dagger $(\dagger)$ preceding their name.

Anatomical abbreviations: ang - angulo-articular; boc - basioccipital; br - branchiostegal rays; cl - cleithrum; den - dentary; ect - ectopterygoid; epi - epineural; fr frontal; haap - articular head of the hyomandibula (anterior facet); hm - hyomandibula; hop - opercular process of the hyomandibula; hpap - articular head of the hyomandibula (posterior facet); hpbr - hypobranchial; hpp - preopercular process of the hyomandibula; le - lateral ethmoid; mtp metapterygoid; mx - maxilla; op - opercle; oto - saccular otoliths; $\mathrm{P}$ - pectoral fin; pa - palatine; $\mathrm{pcl}$ - postcleithrum; phg - pharyngeal tooth patch; pmx - premaxilla; pop preopercle; psph - parasphenoid; pst - posttemporal; q quadrate; scl - supracleithrum; scpc - scapula and coracoid remains; sop - subopercle; sph - sphenotic; V - pelvic fin; v - vomer; vert - vertebrae.

\section{Systematic paleontology}

Division Percomorphacea sensu Wiley \& Johnson, 2010

Order Batrachoidiformes Goodrich, 1909

Family Batrachoididae Bonaparte, 1832

\section{Genus $\nmid$ Louckaichthys gen. nov.}

Type species. - †Louckaichthys novosadi sp. nov.

Etymology. - The generic name is derived from the name of the Loučka locality, situated along the bank of the Loučka stream.

Diagnosis. - Batrachoidid fish with an oblong subopercle having a single spine and no filaments; opercle with two spines and a single filament; preopercle with well-developed articular pedicel emerging along the anterior margin at the confluence between vertical and horizontal arms; robust hyomandibula with well-developed articular, opercular and preopercular processes; at least two pairs of epineurals hypertrophied and robust.

Species included. - Type species only.

\section{$\dagger$ Louckaichthys novosadi sp. nov.}

Figures 2-4

Holotype. - The specimen in part (NMP Pv 10052a; Fig. 2A, B) and counterpart (NMP Pv 10052b; Fig. 2C).

Material. - Holotype only.
Type locality and horizon. - The Loučka locality (Silesian Unit); early Oligocene, Rupelian (32 Ma). The specimen was collected in the Dynów Member of the Menilitic Formation.

Etymology. - The species name is honor of Mr. Bronislav Novosad who collected the specimen and donated it to the NMP collection.

Diagnosis. - As for genus.

Description. - The specimen is partially complete, lacking the posterior portion of the vertebral column, the median fins and their endoskeletal supports, and the pelvic girdles. The bones of the axial skeleton are only weakly articulated or completely disarticulated. As a consequence, it is not possible to take most of the appropriate measurements and to properly evaluate the body proportions (estimated standard length about $150 \mathrm{~mm}$ ). The cephalic part of the body is broad and dorso-ventrally compressed. The fossil is exposed in ventral aspect, and the original morphology of only some of the skeletal elements is fully recognizable due to their fragmentation. Most of the cranial bones are exposed in medial view and in some cases the inner structure is visible.

The neurocranium is only partially complete and moderately well-preserved (Fig. 3). Its estimated length is about $34 \mathrm{~mm}$, measured from the anteriormost margin of the vomer to the posteriormost edge of the basioccipital. Overall, the neurocranium appears to be notably depressed and rather elongate, with the ratio between its maximum length (measured from anterior-most tip of the vomer to the posteriormost margin of the basioccipital) and its width (measured between the two contralateral sphenotic process) being about 1.7. The interorbital portion is narrow. The frontals are recognizable and exhibit crenulated lateral margins. There is no evidence of the mesethmoid. The vomer is exposed in ventral view and shows several tooth sockets. Fragmentary remains of the lateral ethmoids are preserved lateral to the vomer. The vomer articulates posteriorly with the parasphenoid. The neurocranium is notably expanded postorbitally, bearing easily recognizable and posteriorly oriented sphenotic processes. The posterior part of the neurocranium is inadequately preserved and only basioccipital fragments can be tentatively recognized. Remains of the left and right saccular otoliths are recognizable, but their morphology is not clear.

The jaws are extensively damaged, with several tooth fragments recognizable in both the right premaxilla and left dentary. The dentary is elongated and relatively narrow, bearing a well-developed coronoid process postero-dorsally. The angulo-articular does not appear to be involved in the coronoid process, being much lower than the posterior part of the dentary. The articulation of the lower jaw is located at the level of the posterior portion of the orbit. 


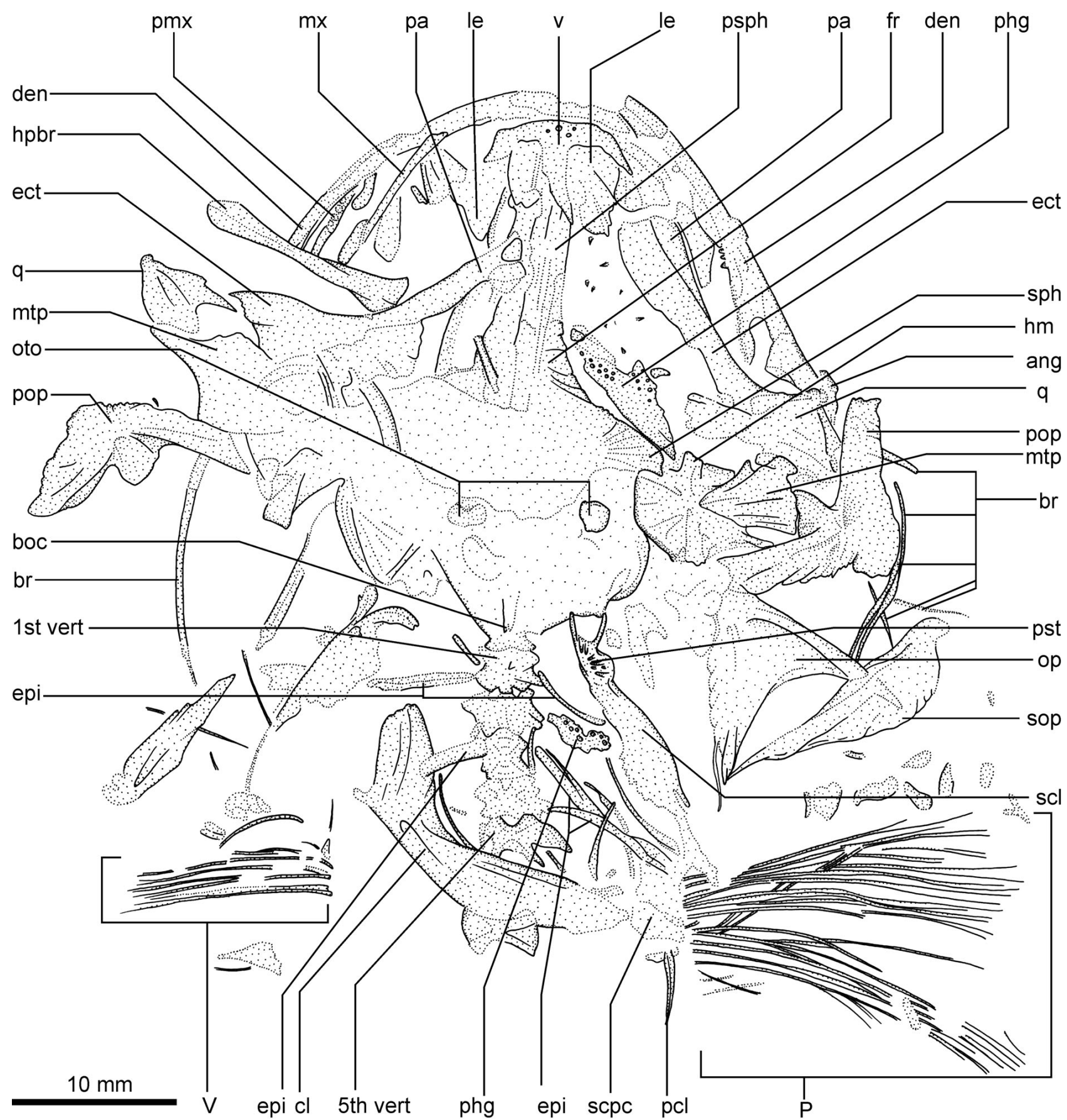

Figure 3. $\dagger$ Louckaichthys novosadi gen. et sp. nov. from the Oligocene of the Loučka locality. Holotype (NMP Pv 10052a). Interpretative drawing of the head skeleton and anterior part of the axial skeleton. For abbreviation see Material and methods.

The quadrate is broad and low, and articulates postero-dorsally with the subtriangular metapterygoid, and anteriorly with the ectopterygoid. The ectopterygoid is flat, with a slightly concave ventral margin; the medial articulation for the palatine is recognizable in the anterior half of the ectopterygoid. The morphology of the palatine is difficult to recognize. The left hyomandibula is well preserved (Fig. 4C); it is relatively robust, short and bears relatively large articular, opercular and preopercular processes. The opercular process is long and well-developed, similar to the ventrally directed preopercular process. The hyomandibula articulates ventrally with the metapterygoid; due to this articulation we are not able to recognize the exact morphology of the ventral margin of the hyomandibula, which is hidden by the metapterygoid. 
The preopercle consists of two arms of similar size forming a nearly right angle (Fig. 4D); the horizontal arm is slightly more massive. The preopercle bears a well-developed and dorsally oriented pedicel with a nearly straight dorsal edge, emerging along its dorsal margin at the angle formed by the convergence of the horizontal and vertical arms. The pedicel probably articulated with the ventral margin of the metapterygoid. The postero-ventral margin of the preopercle is irregular and almost fringed. The opercle (Fig. 4A) is nearly triangular in outline. The horizontal ridge arising from the condyle for the opercular process of the hyomandibula terminates posteriorly in a strong spine; the main thickened shaft of this bone terminates posteroventrally into a blunt spine; the posteroventral margin of the opercle is strongly concave. The dorsal margin of the opercle is thin, with an irregular and fringe-like profile, and characterized by a single filament that emerges in its posterior third. The subopercle is oblong, with nearly straight dorsal and convex postero-ventral margins and terminating posterodorsally in a single thin and elongate spine (Fig. 4B).

The branchial skeleton is poorly preserved and only a single hypobranchial, a few (tooth-bearing) pharyngobranchials and several branchiostegal rays can be recognized.

Of the axial skeleton about 27 vertebrae and their associated epineurals are preserved. At least some of the vertebrae bear robust and anteroposteriorly expanded neural spines, of which the first recognizable preserved element appears to be that of the fifth neural spine. Pleural ribs are not present, but several pairs of epineurals are recognizable; at least two pairs of epineurals are hypertrophied and robust, articulating with the anterior vertebrae.

The pectoral girdle is only partially preserved. The left anteriorly bifurcated posttemporal and its associated elongate supracleitrum are clearly recognizable; these two bones are ankylosed and seem to exhibit a condylar articulation. The cleithrum is crescent-shaped. Scapula and coracoid are poorly preserved and difficult to recognize. The preserved left pectoral fin contains approximately 16 distally bifurcated rays. What appears to be the right pelvic fin is composed by about three rays, plus a thin and short spine. The pelvic girdle is not recognizable.

Discussion. - Despite its incompleteness, the fossil described herein exhibit a set of features that support its recognition as a member of the batrachoidiform family Batrachoididae. The monophyletic status of the Batrachoidiformes and, consequently, of the Batrachoididae, has been extensively debated (e.g., Regan 1912, Monod 1960, Lauder \& Liem 1983, Patterson \& Rosen 1989). Wiley \& Johnson (2010) identified nine synapomorphies for this group, including larvae with an enormous yolk sac bearing an adhesive disc on its ventral surface; "crowded" configuration of dorsal spine/pterygiophore complex; first epineural hypertrophied, robust and ligamentously bound to the medial surface of the cleithrum; five pectoral radials, the uppermost unossified in some genera, the lowermost the largest and with condylar articulation with the coracoid; supracleithrum with condylar articulation with the ankylosed posttemporal; parietal absent; pelvic fin with a very short spine and two soft rays; mesethmoid unossified; and swimbladder with distinctive configuration. The fossil exhibits the typical toadfish physiognomy and a detailed morphological examination of the skeleton allows for the recognition of at least three of these features that clearly justify its inclusion within the Batrachoidiformes (and, likely, the family Batrachoididae), including the possession of an hypertrophied first epineural (Figs 2-3), supracleithrum with condylar articulation with ankylosed posttemporal (see Fig. 3), and mesethmoid unossified.

$\dagger$ Louckaichthys gen. nov. exhibits a unique combination features that make it very difficult to clarify its position within the batrachoiforms but clearly provides evidence of its separate generic status. What appears to be its most interesting feature is the possession of at least two pairs of hypertrophied and robust epineurals. As discussed above, the possession of a single pair of greatly expanded epineurals inserting on the anterior vertebra and ligamentously bound to the medial surface of the cleithrum was regarded by Wiley \& Johnson (2010) as diagnostic for toadfishes. The additional pair of hypertrophied epineurals is apparently unique within the Batrachoidiformes. Moreover, while the single pair of hypertrophied epineurals characteristic of extant toadfishes inserts on the neural arches of the first vertebra and is bound to the medial surface of the cleithrum, the situation is not clear in $\dagger$ Louckaichthys gen. nov. due to inadequate preservation.

What we interpreted as the pelvic fin of $\dagger$ Louckaichthys gen. nov. is only moderately preserved; however, it seems to comprise approximately three soft rays, while only two are considered to be synapomorphic for the group by Wiley \& Johnson (2010). The presence of two or three pelvic-fin rays in batrachoidiforms has been reported by Gosline (1970) and Greenfield et al. (2008); these conditions are considered to be erroneous by Wiley \& Johnson (2010, p. 160). A detailed reexamination of a large sample of individuals of the extant toadfish diversity and better preserved specimens would shed light to this problematic question.

There is no evidence of a subopercular filaments in the $\dagger$ Louckaichthys novosadi gen. et sp. nov. holotype.The absence of subopercular filaments is certainly unique within the batrachoidiforms (see Greenfield et al. 2008, Wiley \& Johnson 2010, Carnevale \& Collette 2014) and unquestionably represents a relevant diagnostic feature for this new Oligocene toadfish. However, it is difficult to define whether the absence of the subopercular filaments should be regarded as the primitive state or a secondary loss. 


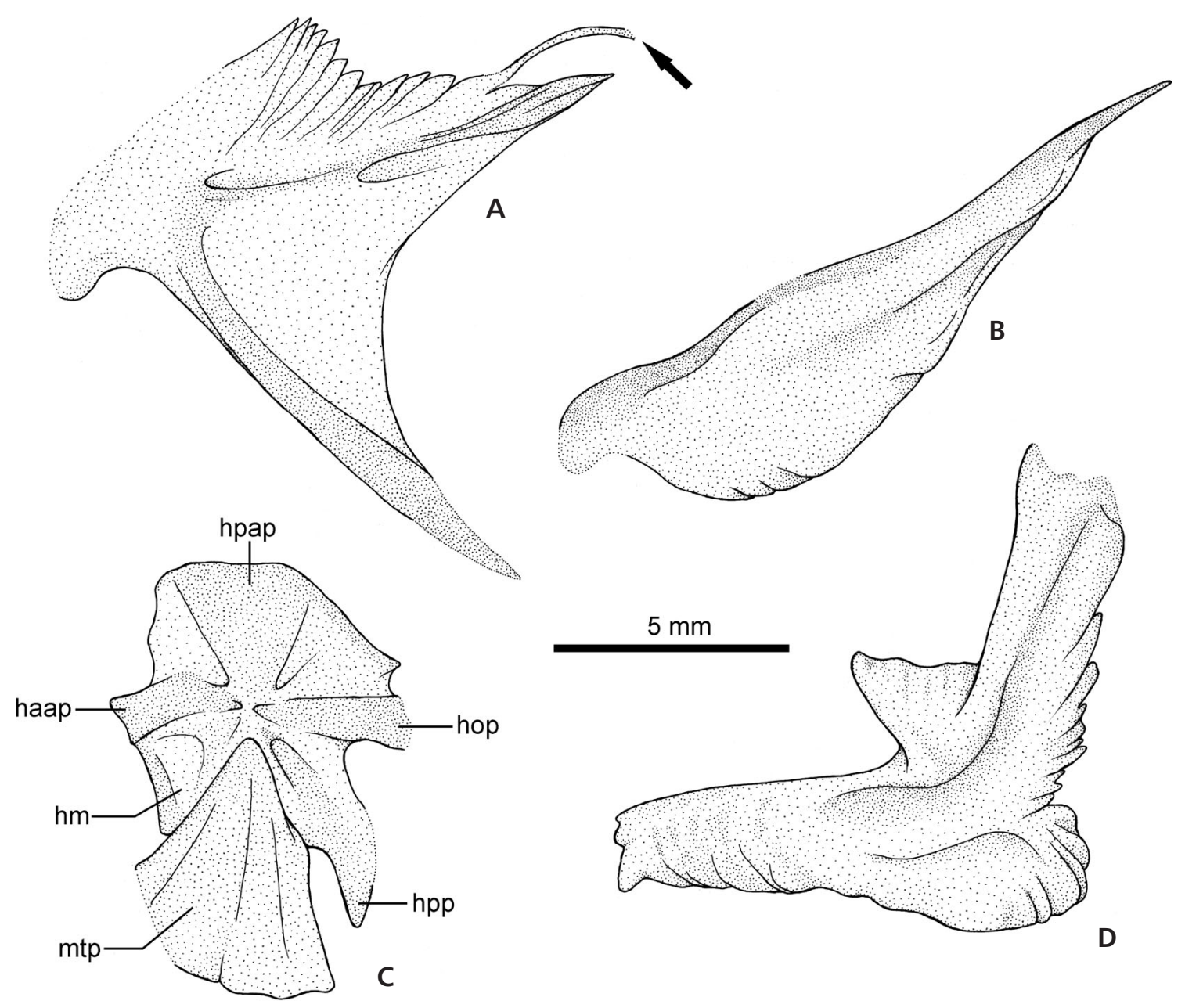

Figure 4. †Louckaichthys novosadi gen. et sp. nov. from the Oligocene of the Loučka locality. Holotype (NMP Pv 10052b). Interpretative drawings of selected skull bones. $\bullet$ A - opercle showing two spines and a single filament (distal tip is marked by arrow; antero-dorsal margin is not preserved well enough to be reconstructed properly). $\bullet \mathrm{B}-$ subopercle. $\bullet \mathrm{C}$ - hyomandibula and associated metapterygoid. $\bullet \mathrm{D}$ - preopercle. For abbreviation see Material and methods.

Finally, †Louckaichthys gen nov. also differs from all the other toadfish genera by having a remarkably well-developed preopercular process of the hyomandibula (see Greenfield et al. 2008), as well as a dorsally oriented and expanded pedicel emerging along the anterior margin of the preopercle at the angle formed by the confluence of its horizontal and vertical arms (see Greenfield et al. 2008).

Summarizing, substantial morphological evidence strongly supports the placement of the Oligocene fossil from the Menilitic Formation described herein in a new batrachoidiform genus. A peculiar and unique set of osteological features seems to indicate that $\dagger$ Louckaichthys gen. nov. is not a member of the currently recognized batrachoidiform lineages (Batrachoidinae, Halophryninae, Porichthyinae, Thalassophryninae). In any case, additional comparative information and anatomical evidence would be desirable to properly interpret its affinities within the Batrachoidiformes and, for this reason, we prefer to postpone any attempt to analyze its phylogenetic relationships until much more complete specimens become available.

\section{Conclusion}

A single articulated skeleton of a new toadfish, $\dagger$ Louckaichthys novosadi gen. et sp. nov., is described herein. Articulated skeletal remains of toadfishes were exclusively known from Miocene deposits, thereby implying that the specimen described herein represents the first Oligocene batrachoidiform described up to date. The specimen exhibits the typical toadfish physiognomy, and at least three morphological features (possession of an hypertrophied first epineural, supracleithrum with condylar articulation with ankylosed posttemporal, mesethmoid unossified) clearly justify its inclusion within the Batrachoidiformes. Despite its incompleteness and partial disarticulation, the 
specimen shows numerous characters that confirm its separate taxonomic status within this group. One of these features - possession of at least two pairs of hypertrophied and robust epineurals - is unique within the batrachoidiforms. A more precise evaluation of the phylogenetic relationships of $†$ Louckaichthys novosadi gen. et sp. nov. is not possible until additional and more complete specimens will be available.

\section{Acknowledgement}

We acknowledge Boris Ekrt (Prague) for access to the specimen under his care; Pavel Lisý (Prague) for taking photos of the holotype, and Miroslav Bubík (Brno) for comments of the geology and stratigraphy of the Loučka locality. We acknowledge James C. Tyler (Washington) and anonymous reviewer for their constructive reviews and comments. The study was financially supported by a grant of the Czech Science Foundation (16-21523S), institutional support by the Institute of Geology of the CAS, v.v.i. (RVO67985831) and by grants (ex-60\% 2015 and 2016) of the Universitŕ degli Studi di Torino.

\section{References}

Arambourg, C. 1927. Les Poissons Fossiles d'Oran. Matériaux Pour la Carte Géologique de l'Algérie, ler SériePaléontologie 6, 1-218.

BAnNiKov, A.F. \& Sorbini, C. 2000. Preliminary note on a Lower Paleocene fish fauna from Trebiciano (Trieste-North-Eastern Italy). Atti del Museo civico di storia naturale di Trieste 48, $15-30$.

Betancur-R., R., Broughton, R.E., Wiley, E.O., Carpenter, K., López, J.A., Li, C., Holcroft, N.I., Arcila, D., Sanciangco, M., Cureton, J.C. II, Zhang, F., Buser, T., Campbell, M.A., Ballesteros, J.A., Roa-Varon, A., Willis, S., Borden, W.C., Rowley, T., Reneau, P.C., Hough, D.J., Lu, G., Grande, T., Arratia, G. \& Ortí, G. 2013. The Tree of Life and a New Classification of Bony Fishes. PLoS Currents Tree of Life. 2013 April 18 (Edition 1).

DOI 10.1371/currents.tol.53ba26640df0ccaee75bb165c8c26288

Bonaparte, C.L. 1832. Saggio d'una distribuzione metodica degli animali vertebrati a sangue freddo. Giornale Arcadico di Scienze, Lettere ed Arti 53, 89-123.

Cappetta, H., GregorovÁ, R. \& Adnet, S. 2016. New selachian assemblages from the Oligocene of Moravia (Czech Republic). Neues Jahrbuch für Geologie und Paläontologie, Abhandlungen 280, 259-284. DOI 10.1127/njgpa/2016/0579

Carnevale, G. 2004. The first fossil ribbonfish (Teleostei, Lampridiformes, Trachipteridae). Geological Magazine 141, 573-582. DOI 10.1017/S0016756804009598

Carnevale, G. \& Collette, B.B. 2014. †Zappaichthys harzhauseri, gen. et sp. nov., a new Miocene toadfish (Teleostei, Batrachoidiformes) from the Paratethys (St. Margarethen in
Burgenland, Austria), with comments on the fossil record of batrachoidiform fishes. Journal of Vertebrate Paleontology 34, 1005-1017. DOI 10.1080/02724634.2014.854801

Carnevale, G. \& Johnson, G.D. 2015. A Cretaceous cusk-eel (Teleostei, Ophidiiformes) from Italy and the Mesozoic diversification of percomorph fishes. Copeia 103, 771-791. DOI 10.1643/CI-15-236

Carnevale, G. \& Godfrey, S.J. In press. Miocene bony fishes of the Calvert, Choptank, St. Marys and Eastover Formation, Chesapeake Group, Maryland and Virginia. Smithsonian Contributions to Paleobiology.

Carnevale, G., Landini, W., Ragaini, L., Cantalamessa, G. \& Di Celma, C. 2011. Taphonomic and paleoecological analyses (mollusks and fishes) of the Súa Member condensed shellbed, Upper Onzole Formation (Early Pliocene, Ecuador). Palaios 26, 160-172. DOI 10.2110/palo.2010.p10-070r

Carnevale, G., Landini, W. \& Sarti, G. 2006. Mare versus Lago-mare. Marine fishes and the Mediterranean environment at the end of the Messinian Salinity Crisis. Journal of the Geological Society, London 163, 75-80.

DOI 10.1144/0016-764904-158

Carnevale, G., Longinelli, A., Caputo, D., Barbieri, M. \& LANDINI, W. 2008. Did the Mediterranean marine reflooding preced the Mio-Pliocene boundary? Paleontological and geochemical evidence from Upper Messinian sequences of Tuscany, Italy. Palaeogeography, Palaeoclimatology, Palaeoecology 257, 81-105.

DOI 10.1016/j.palaeo.2007.09.005

Chen, W.J., Santini, F., Carnevale, G., Chen, J.N., Liu, S.H., LAVoué, S. \& MAYdEN, R.L. 2014. New insights on early evolution of spiny-rayed fishes (Teleostei: Acanthomorpha). Frontiers in Marine Science 1, 1-17.

DOI 10.3389/fmars.2014.00053

Collette, B.B. 1995. Potamobatrachus trispinosus, a new freshwater toadfish (Batrachoididae) from the Rio Tocantins, Brazil. Ichthyological Exploration of Freshwaters 6, 333-336.

Girone, A. \& Nolf, D. 2009. Fish otoliths from the Priabonian (Late Eocene) of North Italy and South-East France - their paleobiogeographical significance. Revue de Micropaleontologie 52, 195-218. DOI 10.1016/j.revmic.2007.10.006

Goodrich, E.S. 1909. Part IX. Vertebrata Craniata, 1-518. In LANKESTER, R. (ed.) A Treatise on Zoology. Kadam and Charles Black, London.

GosLinE, W.A. 1970. A reinterpretation of the teleostean fish order Gobiesociformes. Proceedings of the California Academy of Sciences, 4th series 38, 363-382.

Greenfield, D.W., Winterbottom, R. \& Collette, B.B. 2008. Review of the toadfish genera (Teleostei: Batrachoididae). Proceedings of the California Academy of Sciences 59, 665-710.

Greenwood, P.H., Rosen, D.E., Weitzman, S.H. \& Myers, G.S. 1966. Phyletic studies of teleostean fishes, with a provisional classification of living forms. Bulletin of the American Museum of Natural History 131, 339-456.

GregorovÁ, R. 1988. Rybí fauna menilitového souvrství na 
lokalitě Litenčice a její stratigrafická pozice. Acta Musei moraviae, Scientiae Naturales 73, 83-88.

Gregorová, R. 2011. Fossil fish fauna (Teleostei, Selachii) from the Dynów marlstone (Rupelian, NP 23) of the Menilitic Formation at the locality of Litenčice (Czech Republic). Acta Musei Moraviae, Scientiae geologicae 96, 3-33.

Gregorová, R. Micklich, N. \& PŘIIKRYL, T. 2016. First record of the family Moronidae (Perciformes) in the Menilitic Formation of the Litenčice locality (Oligocene, Rupelian; Moravia, Czech Republic). Neues Jahrbuch für Geologie und Paläontologie, Abhandlungen 280, 79-86. DOI 10.1127/njgpa/2016/0566

Landini, W., Bianucci, G., Carnevale, G., Ragaini, L., Sorbini, C., Valleri, G., Bisconti, M., Cantalamessa, G. \& Di Celma, C. 2002a. Late Pliocene fossils of Ecuador and the evolution of the Panamic Bioprovince after the closure of the Central American Isthmus. Canadian Journal of Earth Sciences 39, 27-41. DOI 10.1139/e01-063

Landini, W., Carnevale, G. \& Sorbini, C. 2002b. Biogeographical significance of northern extraprovincial fishes in the Pliocene of Ecuador. Geobios, Mémoire special 24, 120-129. DOI 10.1016/S0016-6995(02)00053-0

LAUdER, G.V. \& LiEM, K.F. 1983. The evolution and interrelationships of the actinopterygian fishes. Bulletin of the Museum of Comparative Zoology 150, 95-197.

Monod, T. 1960. A propos du pseudobrachium des Antennarius (Pisces, Lophiiformes). Bulletin de l'Institut Français d'Afrique Noire 23, 620-698.

Nolf, D. 1988. Les otolithes de téléostéens éocènes d'Aquitaine et leur intérêt stratigraphique. Academie Royale de Belgique, Mèmoires de la Classe des Sciences 19, 7-147.

Nolf, D. 2013. The Diversity of Fish Otoliths Past and Present. 350 pp. Royal Belgian Institute of Natural Sciences, Brussels.
Patterson, C. \& Rosen, D.E. 1989. The Paracanthopterygii revisited: order and disorder, 5-36. In CoHEN, D.M. (ed.) Papers on the systematic of gadiform fishes. Natural History Museum of the Los Angeles County Science Series 32.

PŘIKRYL, T. 2009. A juvenile Trachinus minutus (Pisces, Perciformes, Trachinidae) from the Middle Oligocene of Litenčice (Moravia, Czech Republic). Acta Musei Nationalis Pragae, Series B, Historia Naturalis 65, 3-8.

PŘikryl, T., Prokofiev, A.M. \& Krzemiński, W. 2012. Feeding habits of the Oligocene bristlemouth fish Scopeloides glarisianus (Teleostei: Stomiiformes: Gonostomatidae). Geobios 45, 377-386. DOI 10.1016/j.geobios.2011.10.012

Purdy, R.W., Schneider, V.P., Applegate, S.P., McLellan, J.H., Meyer, R.L. \& Slaughter, B.H. 2001. The Neogene sharks, rays and bony fishes from Lee Creek Mine, Aurora, North Carolina. Smithsonian Contributions to Paleobiology 90, 71-202.

Ray, C.E., Wetmore, A., Dunkle, D. \& Drez, P. 1968. Fossil vertebrates from the marine Pleistocene of southern Virginia. Smithsonian Miscellaneous Collections 153, 1-25.

REGAn, C.T. 1912. The classification of the teleostean fishes of the order Pediculati. Annals and Magazine of Natural History, series 8, 9, 277-289. DOI 10.1080/00222931208693132

Rosen, D.E. \& Patterson, C. 1969. The structure and relationships of the paracanthopterygian fishes. Bulletin of the American Museum of Natural History 141, 357-474.

STRÁNík, Z. 1981. Lithofacies development and correlation of the Menilite Member of the Carpathian Flysch zone in Moravia. Zemni plyn a nafta 26, 9-18.

Wiley, E.O. \& Johnson, G.D. 2010. A teleost classification based on monophyletic groups, 123-182. In Nelson, J.S, Schultze, H.P. \& Wilson, M.V.H. (eds) Origin and Phylogenetic Interrelationships of Teleosts. Verlag Dr. Friedrich Pfeil, Munich. 